\title{
Influence of Gamma Irradiation on Microbial Load of Peanut (Arachis hypogaea L) Kernels
}

\author{
D. K. Gojiya*, S. P. Cholera and A. M. Joshi \\ Research Scientist, Junagadh Agricultural University, Junagdh, India \\ *Corresponding author
}

\begin{tabular}{l} 
Ke y w o r d s \\
$\begin{array}{l}\text { Gamma Irradiation, } \\
\text { Peanut kernels, } \\
\text { Microbial load, } \\
\text { Moisture content, } \\
\text { D10 value }\end{array}$ \\
\hline $\begin{array}{l}\text { Article Info } \\
\text { Accepted: } \\
\text { 10 July 2020 } \\
\text { Available Online: } \\
\text { 10 August } 2020\end{array}$ \\
\hline
\end{tabular}

\section{A B S T R A C T}

The influence of gamma irradiation on microbial load of different peanut varieties has been assessed. The healthy and mature kernels of peanut variety popular in saurastra region of India viz. GG-20 and TG-37A were naturally contaminated and conditioned with three initial moisture contents $(6.0 \%, 8.5 \%$ and $11.0 \%)$, w.b. and packed in Poly Propylene (PP) bags of $50 \mu$ thickness. These samples were irradiated with different gamma irradiation dose (0 kGy, $2.5 \mathrm{kGy}, 5.0 \mathrm{kGy}, 7.5 \mathrm{kGy}$ and $10.0 \mathrm{kGy})$ and stored at ambient temperature for three months. Microbial load including total plate count, yeast and mold count, E.coliand salmonella were determined for irradiated and non-irradiated peanut kernels. Microbial load of both peanut varieties for tested microorganism significantly increase in non-irradiated samples whereas irradiated samples showed decrease in population for all the conditioned moisture content as storage time progressed. The research data discovered that gamma irradiation dose of $7.5 \mathrm{kGy}$ is the recommended dose for complete elimination of total plate count as well as yeast and mold; whereas the 5.0 $\mathrm{kGy}$ is sufficient for complete killing of E. Coli.in kernels of both peanut varieties. Salmonella was not noticed in any of the samples before irradiation and during whole storage period. There was found no steady pattern in variation in $\mathrm{D}_{10}$ value, for all the tested microorganisms with respect to initial moisture in kernels of both the peanut varieties.

\section{Introduction}

Groundnut or peanut (Arachis hypogaea L.) commonly known as poor people's nut. In most of the emerging countries, peanut kernels are stored as dry seeds and form a massive serve of food; however huge quantities of seeds are lost annually as a result of microbial load as well as insects' attacks. Presently, the inhibition of microbial infestation in food materials is the most persistent food safety problems facing by the food industry. People, all over the globe are demanding for nontoxic food as we all become more concerned about the quality of the food.

Therefore, a range of preservative strategies are used to prevent and reduce infestation of molds and insects. Chemical fumigation with pesticides, such as methyl bromide and phosphine, is practiced for protection of 
stored seeds from pest infestation. However, as necessary as we believe, the excessive use of these chemicals leads to have hostile effects on both food and environment, related with residues and ozone depletion. In addition, the high cost of insecticides, nonavailability of suitable formulation of chemical and packaging, along with the increasing incidence of insecticides necessitate an alternative approach to post harvest pest control.

Fortunately, radiation processing, which is basically a cold process, can kill microorganisms and insects, reduce postharvest losses, and enhance food safety and quality (Loaharanu and Thomas, 2001). Consequently, irradiation is increasingly being applied to disinfest and decontaminate foods and other products, while gaining recognition as an effective quarantine treatment for agricultural produce (IAEA, 2002). Besides drying, radiation is the only alternative to cold processing for food preservation that has a lethal effect on microorganisms (Gojiya et al., 2019). Further, it is the novel method of food preservation suggested for many countries.

\section{Purpose of study}

India's key export markets include the US, the EU, Asian, SAARC countries and West Asia. Although there is a solid assurance from the Government to promote exports of fresh and processed food products, and a strong preparedness on part of the exporters and farmers to export; Indian exports of food products are getting rejections and bans in key markets on surroundings of lack of obedience with food safety and health standards.

Food products have met rejections and even bans in markets such as the US, Vietnam, EU, Saudi Arabia, Japan and Bhutan due to disputes such as presence of more than chemical residues as well as pest and bacterial infestation beyond approved levels.

The gamma irradiation is a physical treatment comprising direct exposure of food to electron or electromagnetic rays, for their long time protection as well as upgrading of quality and safety (Mahindru, 2005). In this process, the isotope cobalt-60 $\quad\left({ }^{60} \mathrm{Co}\right)$ produces electromagnetic $\gamma$-rays which have tremendous energy which swelling and break alongside the molecules DNA chain and preventing them from functioning normally.

As a result, the parasites and microorganisms that have been affected and losing their capabilities of reproducing themselves and they die (Lacroix and Ouattara, 2000). Consequently gamma irradiation provides food safety and enhancing the shelf life of peanut kernel due to its high effectiveness in deactivating pathogenic and spoilage microorganisms without affecting product quality (Ozden and Erkan, 2010).

The application of gamma radiation in food processing has been broadly accepted and is now legally endorsed as a safe and effective technique for maintaining food quality safety. Knowing the techno-economic benefits, about 100 different countries all over the globe have cleared radiation treatments for over more than 100 different food products.

Food irradiation has been recognized by key health organization such as the American Medical Association, Food and Agriculture Organization (FAO), the World Health Organization (WHO), the International Atomic Energy Agency (IAEA) and the Codex Alimentarius Commission, the US Council of Agricultural Science and Technology. Considering the above facts in mind; research project was undertaken with the following objectives. 


\section{Materials and Methods}

\section{Sample preparations}

Healthy and mature kernels of peanut variety GG-20 (Gujarat Groundnut-20) and TG-37A (Trombay Groundnut-37A), popular in sauratra region were procured in bulk from peanut processing industry namely Balikrut Peanut Industries, Junagadh (Gujarat). Since initial moisture content of the two varieties of peanut (GG-20 and TG-37A) kernels was high $\sim 11 \%$ w.b., therefor be tone packaging, the peanut samples were dried at $50 \pm 2{ }^{\circ} \mathrm{C}$ to attain the safe storage moisture level of $\sim 6.0$ $\%$ in a laboratory tray dryer (Gojiyaet al., 2020). After getting initial moisture content, the samples have been conditioned to $6.0,8.5$ and $11.0 \%$ moisture content (w.b.) by adding pre-determined amount of distilled water to the fixed quantity of kernels. The following equation was used to estimate the quantity of distilled water to be added to the peanut kernels (Obi et al., 2014).

Where,

$$
Q=\frac{M(x-y)}{(100-x)}
$$

$\mathrm{Q}=$ Amount of water to be added $(\mathrm{kg})$

$\mathrm{M}=$ Initial weight of sample $(\mathrm{kg})$

$\mathrm{y}=$ Initial moisture content of the sample $(\%$ w.b.)

$\mathrm{x}=$ Final (desired) moisture content of the sample (\% w.b.)

After addition of calculated amount of distilled water, the samples were packed in the peanut kernels sample of $\sim 650$ Grams were packed in virgin Poly Propylene (PP) bags of $50 \mu$ thickness having size: 260 x 200 $\mathrm{mm}$ and sealed by hand sealing machine (Plastic Impulse Hand Sealer, model: POLY SEAL-300mm. After that these samples were stored in incubator at $25^{\circ} \mathrm{C}$ for $24 \mathrm{~h}$ and during the storage, the samples were stirred at every $2 \mathrm{~h}$ during the day time to ensure uniform moisture.

\section{Application of irradiation treatment}

The given irradiation doses in this study were 2.5, 5.0 7.5 and 10.0 kGywith an accuracy of $\pm 5.0 \%$. The absorbed dose was monitored by Ceric- Cerous $100 \times 2 \mathrm{ml}$ ampoules, type dosimeters (Kilo gray Gamma Dosimeter, Batch No: DS-(3)10, Range 1-30 kGy, Bhaba Atomic Research Centre (BARC), NaviMumbai). The dosimeters were calibrated to ISO/ASTM 51205 (E) Standard Practice for use of a Ceric-Cerous Sulfate Dosimetry System, an "International Organization for Standardization" approved by "American Society for Testing and Materials standard". Dosimeters were positioned a box in front, middle and rear side and total dosimeters was 4 per run. Peanut samples were maintained at $20 \pm 2{ }^{\circ} \mathrm{C}$ during irradiation.

\section{Storage of Peanuts Samples}

The peanut variety GG-20 and TG-37A samples were packed in PP bags and irradiated with gamma irradiation@ 2.5, 5.0, 7.5 and $10.0 \mathrm{kGy}$ using ${ }^{60} \mathrm{Co}$. After applying gamma irradiation, Irradiated and nonirradiated (control) samples were stored at ambient temperature.

These irradiated peanut kernel samples of both the varieties were evaluated at one month interval during storage besides just after irradiation, for its microbiological characteristics viz. Total plate count (log $(\mathrm{CFU} / \mathrm{g}))$, Yeast and mould $(\log (\mathrm{CFU} / \mathrm{g})), E$. coli (log (CFU/g)) and Salmonella (log $(\mathrm{CFU} / \mathrm{g}))$.

The radiation resistance $\left(D_{10}\right.$ value $)$ of the tested microbial load (total plate count (TPC), yeast and mold count (YMC), salmonella and Escherichia Coli.) were determined. All the obtained data were statistically analysed. 


\section{Statistical Analysis}

By using factorial complete randomized design (F-CRD) with 15 treatment combinations (3 moisture levels $\mathrm{X} \quad 5$ irradiation doses level) were obtained for each variety of peanut. Treatments having $0.0 \mathrm{kGy}$ gamma irradiation dose (no irradiation) served as control for each variety and each moisture content level. All the 30 treatments were examined for all the biochemical, microbiological as well as sensory evaluation of the sample. The mean values generated from the analysis of each of quality attributes obtained from three replications during the research were subjected to statistical analysis using factorial completely randomized design (F-CRD) and Microsoft Excel as per the procedure suggested by Panse and Sukhatme (1985).

\section{Natural microbial contamination}

Natural microbial inoculation of peanut kernels was most commonly achieved by submersion in aqueous spore suspensions (Prado et al., 1999). 100 gram microbiologically contaminated peanut seed were grinded and submerged in 1 liter distilled water. Filtrates of this solution add into distilled water and mixed thoroughly with peanut sample and shake it at low speed until all of the added water was uniformly absorbed to final moisture content of $11 \%$ (w.b). These contaminated peanut samples incubated at $35 \pm 2{ }^{\circ} \mathrm{C}$ temperature and $80 \%$ relative humidity in incubator for seven days. Samples were analyzed for microbial load after 7 days storage and used for further experiments.

\section{Determination of Microbiological Characteristics of Peanut Kernels}

The microbiological characteristic of peanut was carried out according to standard method recommended by AOAC (2006). All microbiological media were procured from Hi-Media laboratories, Mumbai, India. First of all, the media and all the glass accessories to be used in the analysis were sterilized by autoclaving at $121{ }^{\circ} \mathrm{C}$ for $20 \mathrm{~min}$. The peanut sample was diluted to 1:10 (peanut: distilled water) and was thoroughly shaken for 10-15 min to obtain homogenized suspension of micro-organisms. For preparation of 1:100 dilution, the $1 \mathrm{ml}$ sample from 1:10 dilution was taken with the help of pipette and $9 \mathrm{ml}$ distilled water was added into the prepared solution. The process was repeated up to 1:1000 dilutions with the distilled water. The test tubes containing the diluted samples were immediately closed by cotton plugging. The whole procedure for sample preparation was carried out in laminar air flow (Nova Instruments Pvt. Ltd., Ahmedabad) under aseptic condition.

\section{Radiation-decimal reduction dose $\left(\mathrm{D}_{10^{-}}\right.$ value)}

The radiation resistance $\left(\mathrm{D}_{10^{-}}\right.$-value $)$of the tested microbial load (Total plate count (TPC), Yeast and mold count (YMC), Salmonella and Escherichia Coli.) were determined as follow. $\mathrm{D}_{10}$ value for each tested microbial load was determined for each radiation dose as per standard method suggested by Khalek (2008). The number of viable cells after radiation was divided with the initial viable cell number. For all the strains, survival curves relating to $\log$ (survival) were obtained with irradiation dose. Finally, the $D_{10}$ values or the doses which can reduce the microbial population by $90 \%$ were calculated by using the equation

$D_{10}$ value $=\frac{\mathrm{D}}{(\log N o-\log N)} \ldots$

Where,

$D$ is the radiation dose, 
No is the untreated bioburden, and

$\mathrm{N}$ is the irradiated bioburden.

Graphically $D_{10}$ values were calculated by using Excel's linear regression analysis based on the linearity of the survivor curves in which $D_{10}$ values were taken as the negative reciprocal of the slope of the regression line from dose-response curve, which was constructed by plotting log survival counts against irradiation doses.

\section{Results and Discussion}

\section{Effect of Gamma Irradiation on Total plate count (TPC) of Peanut Kernels}

Total bacterial count is widely used as an indication of the microbiological quality of food. It can be observed that Total plate count of tested microorganism increases in nonirradiated samples whereas, irradiated samples showed decrease in population as storage time progressed. Irradiation treatments induced ionization for the cell of bacteria and direct effects on DNA of nucleus cells (Shea et al., 2000; Temur and Tiryaki, 2013) resulting in death of cell complete elimination was observed at and above the irradiation dose of $7.5 \mathrm{kGy}$. As gamma irradiation dose was enlarged from 0.0 to 10.0 $\mathrm{kGy}$, Total plate count of the peanut kernels reduced significantly. This was true for both peanut kernels varieties and at all the three moisture contents. These results indicate that the higher doses of gamma radiation have vigorously effect on Total plate count.

At zero time after irradiation, it was noted as dose was increased from 0.0 to $10.0 \mathrm{kGy}$, the Total plate count (TPC) in GG-20 peanut kernels severely reduced from $5.81 \mathrm{log}$ $(\mathrm{CFU} / \mathrm{g})$ to $<1 \log (\mathrm{CFU} / \mathrm{g})$ and 6.72 to 7.72 $\log (\mathrm{CFU} / \mathrm{g})$ to $<1 \log$ for the kernels with initial moisture content of $6,8.5$ and $11 \%$ (w.b.), respectively. It was noticed once microbial population reduced due to gamma irradiation it could not be revived again during the subsequent storage period of three month.

For TG-37A variety, as irradiation dose was amplified from 0.0 to $10.0 \mathrm{kGy}$, the Total plate count (TPC) in TG-37A peanut kernels sharply reduced from peanut $5.89 \mathrm{log}$ $(\mathrm{CFU} / \mathrm{g})$ to $<1 \mathrm{log}, 6.73 \mathrm{log}(\mathrm{CFU} / \mathrm{g})$ to $<1$ $\log$ and $6.53 \log (\mathrm{CFU} / \mathrm{g})$ to $<1 \log$ for the kernels with initial moisture content of $6,8.5$ and $11 \%$ (w.b.), respectively. It was also reported that the reduction in Total plate count due to gamma irradiation it could not be recovered again during the subsequent storage period. These findings were in accordance with results noted by Farkas (1983) for (garlic powder, cumin, coriander, turmeric and rosemary), Sharma et al., (1989), Hammadet al., (1987) and El-Zawahry et al., (1985) for different spices and its storage. Hilmy and Suryasaputra, (1981) also reported similar results that the microbes' populations decreased as much as 2-3 log cycles after irradiation with $5 \mathrm{kGy}$ in medicinal herbs. After 6 months of storage, microbial load of irradiated samples further decreased and in the case of microorganisms that survive during irradiation treatment may be more sensitive to environmental conditions.

The statistical interpretation of Total plate count of both peanut variety were presented in the Table 1 indicated that during entire storage of GG-20 and TG-37A peanut kernels, the individual effect of gamma irradiation dose (D) and its interaction effect with peanut kernels initial moisture content (D $\mathrm{X} \quad \mathrm{M}$ ) had statistically significant difference at $5 \%$ level of significance. The individual effect of initial moisture content (M) had found significant $(\mathrm{P}<0.05)$ in $\mathrm{GG}-20$ whereas in TG-37A it noted non-significant $(\mathrm{P} \geq 0.05)$ during entire storage. 
Table.1 Effect of gamma irradiation on Total plate count $(\log (\mathrm{CFU} / \mathrm{g}))$ of peanut kernels conditioned at different initial moisture content during storage

\begin{tabular}{|c|c|c|c|c|c|c|c|c|}
\hline \multirow[t]{3}{*}{ Effect } & \multicolumn{4}{|c|}{ GG-20 } & \multicolumn{4}{|c|}{ TG-37A } \\
\hline & \multicolumn{4}{|c|}{ Storage period (month) } & \multicolumn{4}{|c|}{ Storage period (month) } \\
\hline & $\begin{array}{c}0 \text { month } \\
\text { (Initial value) }\end{array}$ & $1^{\text {st }}$ month & $2^{\text {nd }}$ month & $3^{\text {rd }}$ month & $\begin{array}{c}\text { 0 month } \\
\text { (Initial value) }\end{array}$ & $1^{\text {st }}$ month & $2^{\text {nd }}$ month & $3^{\text {rd }}$ month \\
\hline (1) & $(2)$ & (3) & (4) & $(5)$ & $(6)$ & (7) & (8) & (9) \\
\hline \multicolumn{9}{|c|}{ Gamma radiation doses (D) } \\
\hline D1 (0 kGy) & 6.75 & 6.96 & 7.18 & 6.86 & 6.50 & 6.60 & 6.81 & 7.03 \\
\hline D2 (2.5 kGy) & 3.76 & 3.98 & 4.19 & 3.87 & 3.70 & 3.91 & 4.12 & 4.34 \\
\hline D3 (5.0 kGy) & 1.69 & 1.89 & 2.12 & 1.79 & 1.04 & 1.10 & 1.15 & 1.47 \\
\hline D4 (7.5 kGy) & 0.32 & 0.38 & 0.43 & 0.35 & 0.83 & 0.90 & 0.85 & 0.99 \\
\hline D5 (10 kGy) & 0 & 0 & 0 & 0 & 0.11 & 0.14 & 0.14 & 0.18 \\
\hline S.Em \pm & 0.13 & 0.15 & 0.16 & 0.16 & 0.11 & 0.12 & 0.14 & 0.16 \\
\hline $\mathrm{CD}$ at $5 \%$ & 0.37 & 0.42 & 0.46 & 0.45 & 0.32 & 0.35 & 0.40 & 0.46 \\
\hline \multicolumn{9}{|c|}{ Moisture Content (M) } \\
\hline M1 $(6.0 \%, w . b)$ & 2.82 & 2.98 & 3.14 & 3.30 & 2.31 & 2.50 & 2.64 & 2.82 \\
\hline M1 $(8.5 \%, w . b)$ & 3.12 & 3.30 & 3.47 & 3.65 & 2.52 & 2.61 & 2.70 & 2.95 \\
\hline M1 (11.0\%,w.b) & 3.46 & 3.63 & 3.82 & 3.96 & 2.47 & 2.48 & 2.52 & 2.65 \\
\hline S.Em \pm & 0.10 & 0.11 & 0.12 & 0.12 & 0.09 & 0.10 & 0.11 & 0.12 \\
\hline $\mathrm{CD}$ at $5 \%$ & 0.28 & 0.33 & 0.36 & 0.35 & NS & NS & NS & NS \\
\hline \multicolumn{9}{|l|}{ Interaction (D x M) } \\
\hline S.Em \pm & 0.22 & 0.25 & 0.28 & 0.27 & 0.19 & 0.21 & 0.24 & 0.28 \\
\hline $\mathrm{CD}$ at $5 \%$ & 0.64 & 0.73 & 0.80 & 0.78 & 0.56 & 0.61 & 0.68 & 0.80 \\
\hline C.V.\% & 15.23 & 16.53 & 17.54 & 15.98 & 13.83 & 14.58 & 15.68 & 17.04 \\
\hline
\end{tabular}


Table.2 Effect of gamma irradiation on Yeast and Mold count $(\log (\mathrm{CFU} / \mathrm{g}))$ in peanut kernels conditioned at different initial moisture content during storage

\begin{tabular}{|c|c|c|c|c|c|c|c|c|}
\hline \multirow[t]{3}{*}{ Effect } & \multicolumn{4}{|c|}{ GG-20 } & \multicolumn{4}{|c|}{ TG-37A } \\
\hline & \multicolumn{4}{|c|}{ Storage period (month) } & \multicolumn{4}{|c|}{ Storage period (month) } \\
\hline & $\begin{array}{c}\text { 0 month } \\
\text { (Initial value) }\end{array}$ & $1^{\text {st }}$ month & $2^{\text {nd }}$ month & $3^{\text {rd }}$ month & $\begin{array}{c}\text { 0 month } \\
\text { (Initial value) }\end{array}$ & $\mathbf{1}^{\text {st }}$ month & $2^{\text {nd }}$ month & $3^{\text {rd }}$ month \\
\hline (1) & (2) & (3) & (4) & (5) & (6) & (7) & (8) & (9) \\
\hline \multicolumn{9}{|c|}{ Gamma radiation doses (D) } \\
\hline D1 (0 kGy) & 5.77 & 6.02 & 6.24 & 6.45 & 5.97 & 5.98 & 6.00 & 6.01 \\
\hline D2 (2.5 kGy) & 3.30 & 3.51 & 3.73 & 3.94 & 3.28 & 3.30 & 3.31 & 3.33 \\
\hline D3 (5.0 kGy) & 1.80 & 2.01 & 2.22 & 2.44 & 1.16 & 1.17 & 1.18 & 1.20 \\
\hline D4 (7.5 kGy) & 0.21 & 0.26 & 0.35 & 0.42 & 0.41 & 0.41 & 0.42 & 0.42 \\
\hline D5 (10 kGy) & 0 & 0 & 0 & 0 & 0.18 & 0.20 & 0.21 & 0.22 \\
\hline S.Em \pm & 0.05 & 0.07 & 0.08 & 0.09 & 0.08 & 0.08 & 0.08 & 0.08 \\
\hline $\mathrm{CD}$ at $5 \%$ & 0.15 & 0.19 & 0.23 & 0.26 & 0.24 & 0.24 & 0.23 & 0.24 \\
\hline \multicolumn{9}{|c|}{ Moisture Content (M) } \\
\hline M1 (6.0 \%, w.b) & 2.48 & 2.68 & 2.87 & 2.87 & 2.00 & 2.01 & 2.02 & 2.03 \\
\hline M1 (8.5\%, w.b) & 2.89 & 3.05 & 3.24 & 3.24 & 2.76 & 2.77 & 2.78 & 2.80 \\
\hline M1 (11.0\%, w.b) & 3.85 & 4.07 & 4.28 & 4.28 & 3.48 & 3.49 & 3.51 & 3.52 \\
\hline S.Em \pm & 0.04 & 0.05 & 0.06 & 0.07 & 0.06 & 0.06 & 0.06 & 0.06 \\
\hline $\mathrm{CD}$ at $5 \%$ & 0.11 & 0.15 & 0.18 & 0.20 & NS & NS & NS & NS \\
\hline \multicolumn{9}{|l|}{ Interaction (D x M) } \\
\hline S.Em \pm & 0.09 & 0.12 & 0.14 & 0.16 & 0.14 & 0.14 & 0.14 & 0.14 \\
\hline $\mathrm{CD}$ at $5 \%$ & 0.25 & 0.33 & 0.40 & 0.46 & 0.42 & 0.41 & 0.40 & 0.41 \\
\hline C.V.\% & 6.86 & 8.50 & 9.64 & 10.45 & 11.93 & 11.60 & 11.46 & 11.61 \\
\hline
\end{tabular}


Table.3 Effect of gamma irradiation on E. Coli. $(\log (\mathrm{CFU} / \mathrm{g}))$ in peanut kernels conditioned at different initial moisture content during storage

\begin{tabular}{|c|c|c|c|c|c|c|c|c|}
\hline \multirow[t]{3}{*}{ Effect } & \multicolumn{4}{|c|}{ GG-20 } & \multicolumn{4}{|c|}{ TG-37A } \\
\hline & \multicolumn{4}{|c|}{ Storage period (month) } & \multicolumn{4}{|c|}{ Storage period (month) } \\
\hline & $\begin{array}{c}0 \text { days } \\
\text { (Initial value) }\end{array}$ & 30 & 60 & 90 & $\begin{array}{c}\text { 0 days } \\
\text { (Initial value) }\end{array}$ & 30 & 60 & 90 \\
\hline (1) & (2) & (3) & (4) & (5) & (6) & (7) & (8) & (9) \\
\hline \multicolumn{9}{|c|}{ Gamma radiation doses (D) } \\
\hline D1 (0 kGy) & 2.29 & 2.28 & 2.28 & 2.29 & 2.10 & 2.09 & 2.08 & 2.08 \\
\hline D2 (2.5 kGy) & 1.21 & 1.21 & 1.22 & 1.22 & 1.41 & 1.42 & 1.43 & 1.43 \\
\hline D3 (5.0 kGy) & 0 & 0 & 0 & 0 & 0 & 0 & 0 & 0 \\
\hline D4 (7.5 kGy) & 0 & 0 & 0 & 0 & 0 & 0 & 0 & 0 \\
\hline D5 (10 kGy) & 0 & 0 & 0 & 0 & 0 & 0 & 0 & 0 \\
\hline S.Em \pm & 0.01 & 0.02 & 0.02 & 0.01 & 0.03 & 0.03 & 0.03 & 0.03 \\
\hline $\mathrm{CD}$ at $5 \%$ & 0.04 & 0.05 & 0.06 & 0.04 & 0.07 & 0.07 & 0.09 & 0.07 \\
\hline \multicolumn{9}{|c|}{ Moisture Content (M) } \\
\hline M1 (6.0 \%, w.b) & 1.66 & 1.66 & 1.66 & 1.67 & 1.643 & 1.633 & 1.630 & 1.634 \\
\hline M1 (8.5 \%, w.b) & 1.68 & 1.69 & 1.69 & 1.69 & 1.741 & 1.741 & 1.744 & 1.745 \\
\hline M1 (11.0\%, w.b) & 1.90 & 1.90 & 1.90 & 1.91 & 1.877 & 1.883 & 1.882 & 1.880 \\
\hline S.Em \pm & 0.01 & 0.01 & 0.02 & 0.01 & 0.02 & 0.02 & 0.02 & 0.02 \\
\hline $\mathrm{CD}$ at $5 \%$ & 0.03 & 0.04 & 0.05 & 0.03 & 0.06 & 0.06 & 0.07 & 0.06 \\
\hline \multicolumn{9}{|l|}{ Interaction (D x M) } \\
\hline S.Em \pm & 0.02 & 0.03 & 0.04 & 0.02 & 0.04 & 0.04 & 0.05 & 0.04 \\
\hline $\mathrm{CD}$ at $5 \%$ & 0.06 & 0.09 & 0.10 & 0.06 & 0.13 & 0.13 & 0.15 & 0.13 \\
\hline C.V.\% & 5.47 & 7.63 & 8.90 & 5.28 & 10.87 & 10.78 & 13.04 & 10.78 \\
\hline
\end{tabular}


Table.4 Effect of gamma irradiation on Salmonella $(\log (\mathrm{CFU} / \mathrm{g}))$ in peanut kernels conditioned at different initial moisture content during storage

\begin{tabular}{|c|c|c|c|c|c|c|c|c|}
\hline \multirow[t]{3}{*}{ Effect } & \multicolumn{4}{|c|}{ GG-20 } & \multicolumn{4}{|c|}{ TG-37A } \\
\hline & \multicolumn{4}{|c|}{ Storage period (month) } & \multicolumn{4}{|c|}{ Storage period (month) } \\
\hline & $\begin{array}{c}\text { 0 month } \\
\text { (Initial value) }\end{array}$ & $1^{\text {st }}$ month & $2^{\text {nd }}$ month & $3^{\text {rd }}$ month & $\begin{array}{c}\text { 0 month } \\
\text { (Initial value) }\end{array}$ & $1^{\text {st }}$ month & $2^{\text {nd }}$ month & $3^{\text {rd }}$ month \\
\hline (1) & $(2)$ & (3) & (4) & $(5)$ & $(6)$ & (7) & (8) & (9) \\
\hline \multicolumn{9}{|c|}{ Gamma radiation doses (D) } \\
\hline D1 (0 kGy) & Absent & Absent & Absent & Absent & Absent & Absent & Absent & Absent \\
\hline D2 (2.5 kGy) & Absent & Absent & Absent & Absent & Absent & Absent & Absent & Absent \\
\hline D3 (5.0 kGy) & Absent & Absent & Absent & Absent & Absent & Absent & Absent & Absent \\
\hline D4 (7.5 kGy) & Absent & Absent & Absent & Absent & Absent & Absent & Absent & Absent \\
\hline D5 (10 kGy) & Absent & Absent & Absent & Absent & Absent & Absent & Absent & Absent \\
\hline S.Em \pm & - & - & - & - & - & - & - & - \\
\hline $\mathrm{CD}$ at $5 \%$ & - & - & - & - & - & - & - & - \\
\hline \multicolumn{9}{|c|}{ Moisture Content (M) } \\
\hline M1 (6.0\%, w.b) & Absent & Absent & Absent & Absent & Absent & Absent & Absent & Absent \\
\hline M1 (8.5 \%, w.b) & Absent & Absent & Absent & Absent & Absent & Absent & Absent & Absent \\
\hline M1 (11.0 \%, w.b) & Absent & Absent & Absent & Absent & Absent & Absent & Absent & Absent \\
\hline S.Em \pm & - & - & - & - & - & - & - & - \\
\hline $\mathrm{CD}$ at $5 \%$ & - & - & - & - & - & - & - & - \\
\hline \multicolumn{9}{|l|}{ Interaction (D x M) } \\
\hline S.Em \pm & - & - & - & - & - & - & - & - \\
\hline $\mathrm{CD}$ at $5 \%$ & - & - & - & - & - & - & - & - \\
\hline C.V.\% & - & - & - & - & - & - & - & - \\
\hline
\end{tabular}


Table.5 Radiation-decimal reduction dose ( $\mathrm{D}_{10}$-value)

\begin{tabular}{|c|c|c|c|c|}
\hline \multirow{2}{*}{$\begin{array}{l}\text { SSr. } \\
\text { No }\end{array}$} & \multirow{2}{*}{$\begin{array}{l}\text { Microbial Parameter, } \\
\quad(\log \text { CFU/g) }\end{array}$} & \multirow{2}{*}{$\begin{array}{l}\text { Moisture content, } \\
\text { w.b }(\%)\end{array}$} & \multicolumn{2}{|c|}{$\mathrm{D}_{10}$ values in $\mathrm{kGy}$} \\
\hline & & & GG-20 & TG-37A \\
\hline (1) & (2) & (3) & (4) & (5) \\
\hline \multirow[t]{3}{*}{11} & \multirow{3}{*}{ Total Plate Count } & $\mathrm{M} 1=6.0 \%$ & 0.83 & 1.09 \\
\hline & & $\mathrm{M} 2=8.5 \%$ & 0.97 & 1.02 \\
\hline & & $\mathrm{M} 3=11 \%$ & 1.26 & 1.09 \\
\hline \multirow[t]{3}{*}{22} & \multirow[t]{3}{*}{ Yeast and Mold Count } & $\mathrm{M} 1=6.0 \%$ & 1.21 & 1.07 \\
\hline & & $\mathrm{M} 2=8.5 \%$ & 1.06 & 0.96 \\
\hline & & $\mathrm{M} 3=11 \%$ & 1.57 & 0.92 \\
\hline \multirow[t]{3}{*}{3} & \multirow[t]{3}{*}{ E. Coli. } & $\mathrm{M} 1=6.0 \%$ & 2.18 & 4.40 \\
\hline & & $\mathrm{M} 2=8.5 \%$ & 2.19 & 3.84 \\
\hline & & $\mathrm{M} 3=11 \%$ & 2.61 & 3.11 \\
\hline
\end{tabular}

\section{Effect of Gamma Irradiation on Yeast and mold counts of Peanut Kernels}

The results pertaining to effect of gamma irradiation dose on Yeast and mold counts of both peanut varieties at different initial moisture content during whole storage period reported in Table 2 . It can be evidently seen from data that Yeast and mold count decrease with increase in gamma irradiation dose, at and above $7.5 \mathrm{kGy}$ gamma irradiation dose, Yeast and mold in both the peanut kernels varieties reduced below $1 \log (\mathrm{CFU} / \mathrm{g})$.

It was noted that on initial day after gamma irradiation, as dose increased from 0.0 to 10.0 $\mathrm{kGy}$, Yeast and mold counts in GG-20 peanut kernels significantly $(\mathrm{P}<0.05)$ declined from 5.95 to $<1 \log (\mathrm{CFU} / \mathrm{g}), 6.18$ to $<1 \log$ (CFU/g) and 7.26 to $<1 \log (\mathrm{CFU} / \mathrm{g})$ for the kernels with initial moisture content of $6,8.5$ and $11 \%$ (w.b.), respectively.

The data shows that the reduction in yeast and mold counts could not be recovered again during the consequent storage period. Yeast and mold reportedmaximum in the treatment F1D1M3 (7.81 log (CFU/g)) followed by F1D1M2 ((7.44 log (CFU/g)) and F1D1M1 (7.09 $\log (\mathrm{CFU} / \mathrm{g}))$ after three month of storage.
It was also noticed that, Yeast and mold counts in TG-37A peanut kernels significantly decrease from 5.95 to $<1 \log 7.09$ (CFU/g), 6.18 to $<1 \log (\mathrm{CFU} / \mathrm{g})$ and 7.26 to $<1 \log$ $(\mathrm{CFU} / \mathrm{g})$ with increase in gamma irradiation dose level $0,2.5,5.0,7.5$ and $10.0 \mathrm{kGy}$ at different initial moisture content $(6.0$ to $11 \%$ (w.b.)). The maximum rise in yeast and mold counts was found in the treatment F2D1M3 (7.45 $\log (\mathrm{CFU} / \mathrm{g}))$ followed by F2D1M2 ((6.96 log (CFU/g)) and F2D1M1 (6.31 log $(\mathrm{CFU} / \mathrm{g}))$ samples after three month of storage (Table 2). The similar results were reported by Silberstein et al., (1979) for onion powder, Farkas (1983) and Sharma et al., (1984) for spices, Ramamurthy et al., (2004) for capsicum, Yun et al., (2012) for soybeans (Glycine $\max$ L. Merrill) and Ashtariet al., (2019) for pomegranate cv. Malas-e-Saveh that gamma irradiation significantly reduced the population of bacteria, fungi and yeasts in all this product.

The statistical analysis of Yeast and mold counts of both peanut variety were the indicated that during entire storage of GG-20 and TG-37A peanut kernels, the individual effect of gamma irradiation dose (D) and its interaction effect with peanut kernels' initial moisture content (D X M) had statistically significant difference at $5 \%$ level of 
significance. The individual effect of initial moisture content $(\mathrm{M})$ had found significant $(\mathrm{P}<0.05)$ in $\mathrm{GG}-20$ peanut kernels while in TG-37A it noted non-significant $(\mathrm{P} \geq 0.05)$ during entire storage.

\section{Escherichia coli (E. coli)}

The Escherichia coli (E.coli) of both peanut varieties irradiated with different doses level and different initial moisture content and stored for three month period are reported in Table 3. It can be observed from data that E.coli decrease with increase in gamma irradiation dose and at and above gamma irradiation dose $5.0 \mathrm{kGy}$, E.coliin both the peanut kernels varieties reduced below $1 \log$ (CFU/g).

During initial day of storage it was noticed that as gamma irradiation dose increased from 0.0 to $10.0 \mathrm{kGy}$, E.coli in GG-20 peanut kernels significantly decline from 2.23 to $<1$ $\log (\mathrm{CFU} / \mathrm{g}), 2.25$ to $<1 \log (\mathrm{CFU} / \mathrm{g})$ and 2.38 to $<1 \log (\mathrm{CFU} / \mathrm{g})$ for the kernels having initial moisture content of $6,8.5$ and $11 \%$ (w.b.), respectively. The maximum survival of E.coli was found in the treatment F1D1M3 $(2.32 \log (\mathrm{CFU} / \mathrm{g}))$ followed by F1D1M2 $(2.25 \mathrm{log}(\mathrm{CFU} / \mathrm{g}))$ and F1D1M1 (2.23 log $(\mathrm{CFU} / \mathrm{g}))$ after three month of storage.

It was noted, as gamma irradiation dose was increased from 0.0 to $10.0 \mathrm{kGy}$, E.coli in TG37A peanut kernels significantly reduced from 1.91 to $<1 \log$ (CFU/g), 2.07 to $<1 \log$ (CFU/g) and 2.28 to $<1 \log (\mathrm{CFU} / \mathrm{g})$ for the kernels having initial moisture content of 6 , 8.5 and $11 \%$ (w.b.), respectively. The end of three month storage, the maximum survival of E.coli was reported in non- irradiated treatment F2D1M3 (2.27 log $\quad(\mathrm{CFU} / \mathrm{g}))$ followed by F2D1M2 (2.06 log (CFU/g)) and F2D1M1 (2.27 log (CFU/g)).

These results are in agreement with previous findings of Farkas (1988) for artificially contaminated coconut, Singh et al., (1988) in spices (Turmeric, black pepper, chilli), Swailam and Abdullah (2002) for spices and herbs found same results.

The statistical interpretation of noted E.colidata of both peanut varieties was presented in the Table 3. It indicates that the individual effect of initial moisture content (M) and gamma irradiation dose levels (D) giving significant values $(\mathrm{P}<0.05)$ while its interaction effect (D $\mathrm{X} \quad \mathrm{M}$ ) also found statistically significant at 5\% level of significance for both peanut variety during entire storage periods.

\section{Salmonella}

The Salmonella in both peanut varieties irradiated with different gamma irradiation doses with different initial moisture content, packed in poly propylene bag (PP) and stored at room temperature for three month storage was not noticed in any of the samples during whole storage period.

\section{Radiation-decimal reduction dose $\left(\mathrm{D}_{10}\right.$ - value)}

Microorganisms vary significantly in their resistance to gamma radiation and differences in radiation resistances from species to another and even among strains of the same species with different in condition. The microorganism's resistance against radiation is measured in terms of decimal reduction dose $\left(\mathrm{D}_{10}\right.$-value). $\mathrm{D}_{10}$-value can be defined, as the radiation dose (kGy) essential for killing $90 \%$ of the load of a microbe (Ingram and Roberts, 1980). Therefore, $D_{10}$-values of potentially microbial load (Total plate count (TPC), yeast and mold count (YMC) and Escherichia Coli.) in peanut kernels varieties namely GG-20 and TG-37A at three different (6.0, 8.5 and $11 \%$, w.b) initial moisture content were determined. $\mathrm{D}_{10}$-value of a 
microbe can be determined from dose response curve of the microbe, which is obtained by plotting the number of surviving cells against radiation dose (kGy). The effect of increment doses of gamma irradiation on the Total plate count (TPC), Yeast and mold count (YMC) and Escherichia Coli. noted in Table 4.

From the radiation survival curves; it was found that the $\mathrm{D}_{10}$ value (calculated from linear regression and equation) of $E$. coli (it had the highest radiation resistant among other tested microorganism) was $4.40 \mathrm{kGy}$, $4.40 \mathrm{kGy}$ and $3.84 \mathrm{kGy}$ in TG-37A and 2.18 kGy, $2.19 \mathrm{kGy}$ and $2.61 \mathrm{kGy}$ in GG-20 peanut kernels at 6, 8.5 and $11 \%$, w.b moisture content respectively. The $\mathrm{D}_{10}$ value of Total plate count in GG-20 was noted $0.83 \mathrm{kGy}$, $0.97 \mathrm{kGy}$ and $1.26 \mathrm{kGy}$, while in TG-37A peanut kernels it was found $1.09 \mathrm{kGy}, 1.02$ kGy and $1.09 \mathrm{kGy}$ at $6,8.5$ and $11 \%$, w.b moisture content respectively. In case of GG20 peanut kernels, $\mathrm{D}_{10}$ value of yeast and mold count was revealed $1.21 \mathrm{kGy}, 1.06 \mathrm{kGy}$ and $1.57 \mathrm{kGy}$ whereas it observed $1.07 \mathrm{kGy}$, $0.96 \mathrm{kGy}$ and $0.92 \mathrm{kGy}$ in TG-37A kernels at $6,8.5$ and $11 \%$, w.b moisture content respectively. There were no steady patterns of $\mathrm{D}_{10}$ values change with respect to initial moisture were observed in both peanut varieties.

Knowledge of the $\mathrm{D}_{10}$-value of different microorganisms from survival curves (doseresponse curves) is very needful in calculating the lethal and sub-lethal dose of microorganisms. It is also useful in providing information about the relative resistance of particular microorganisms to ionizing radiation and calculating the exact radiation dose required for 5-log cycle's reduction of pathogenic bacteria and mycotoxin production fungi, which is very important for the practical application of ionizing radiation. By knowing the $\mathrm{D}_{10}$-value of any microorganisms and its level in a product (food, feed, medicinal or pharmaceutical products) one can calculate the exact irradiation dose required to eliminate that microorganisms from that product.

Many researchers have reported the similar variations in radio sensitivity of different microbial species. Generally spore-forming bacteria are more resistant (Aziz and Moussa, 2004). Relatively similar result also reported by Hammad and El-Bazza (1988) and Thayer and Boyd (1993) in $\mathrm{D}_{10}$-value of Escherichia coli isolated from dry foods. Youssef et al., (1999) also observed complete inhibition of fungi by gamma irradiation doses from 4 to 6 $\mathrm{kGy}$ in different food and feed products. It can be said that irradiation dose of about 7.2 kGy (considering max $\mathrm{D}_{10}$ value $1.2 \mathrm{kGy}$ ) required for the acceptable 6 (six) $\log$ reductions of the microbial load. Al-Bachiret al., (2004) reported $D_{10}$ value of total count was about $1.4 \mathrm{kGy}$ in licorice root products.

In conclusion the research data discovered from this research suggest that the gamma irradiation is proficient technology to control microbial load including total plate count, yeast and mold count, E.coli with respect to initial moisture of peanut kernels. The report also advocates that the gamma irradiation can control the microbial load of both the varieties of peanut kernels, just after irradiation and during storage. Gamma irradiation dose of 7.5 $\mathrm{kGy}$ is the sufficient dose for complete elimination of total plate count as well as yeast and mold; whereas the $5.0 \mathrm{kGy}$ is sufficient for complete killing of E. Coli.in kernels of both peanut varieties.

\section{Acknowledgments}

The authors would like to thank Prof. D. M. Vyas and The Junagadh Agricultural University for cooperation and provided necessary facilities to achieve the desired goals of this research. 


\section{References}

Al-Bachir, M. 2004. Effect of gamma irradiation on fungal load, chemical and sensory characteristics of walnuts (Juglans regia L.). Journal of Stored Products Research. 40(4): 355-362.

AOAC. 2006. "Official Methods of Analysis". Association of Official Analytical Chemists. Washington, USA.

Ashtari, M., Orang, K., Mahmoud, S., Hamideh, A. and Mohammad, A. A. S. 2019. Effect of gamma irradiation on antioxidants, microbiological properties and shelf life of pomegranate arils cv. 'MalasSaveh'. Scientia Horticulturae. 244(1): 365-371.

Aziz, N. H. and Moussa, L. A. A. 2004. Reduction of fungal and mycotoxins formation in seeds by gamma radiation. $\mathrm{Ph}$. D. Thesis (Unpublished). Faculty of Science, Ain Shams University, Egypt.

Dionisio, A. P., Gomes, R. T. and Oetterer, M. 2009. Ionizing radiation effects on food vitamins - a review. Brazilian Archives of Biology and Technology. 52(5): 12671278.

El-Zawahry, Y. A., Youssef, Y. A., Awny, N. M. and Hussein, H. A. 1985. Bacterial flora of spices and its control by gamma irradiation. Egyptian Journal of Radiation Sciences and Applications. 2(1): 57-68.

Farkas, J. (Ed.). 1988. Irradiation of dry food ingredients. CRC Press, Boca Raton, FL.

Farkas, J. 1983. Radurization and radicidation of spices. In: Josephson, E.S. and Peterson, M.S.: Preservation of food by ionizing radiation. CRC Press, Inc. Boca Raton, V. III, pp. 109-128.

Gojiya, D.K., 2020. Studies on Physical and Engineering Characteristics of Peanut Kernel. India. Int $J$ NutrSci\& Food Tech, 6:2-22.

Gojiya, DK, Naliapara, VA and Vyas, DM. 2019. Studies on effect of gamma irradiation on biochemical characteristics of peanut kernels (Arachis hypogaea L.). International Journal of Chemical
Studies.7 (5): 1429-1434.

Hammad, A. I. and El-Bazza, Z. E. 1988. Molds contaminating smoked herring and their control by gamma irradiation. Al- Azhar J. Microbiolo. 4:10-23.

Hammad, A. I., Abd El-Aal, S. S. and El-Rify, N. 1987. Radiation decontamination of some important spices from its bacterial load. Egyptian Journal of Applied Science.3(1): 273-281.

Hilmy, N., and Suryasaputra, C. 1981. Radiopasteurization of traditional herbal medicine. Majalah BATAN. 14(1): 41-58.

IAEA. 2002 b. Study of the impact of food irradiation on preventing losses: Experience in Africa. International Atomic Energy Agency TECDOC-1291, Proc. RCM, Pretoria, RSA.

Khalek h. h. A. 2008. Effect of $\gamma$-irradiation on the microbial, chemical quality and the biological activity of some spices and herbs. Ph. D. Thesis (Unpublished). Department of Food Science, Faculty of Agriculture, Cairo University, EGYPT.

Lacroix, M. and Ouattara, B. 2000. Combined industrial processes with irradiation to assure innocuity and preservation of food products - a review. Food Research International. 33(9): 719-724.

Loaharanu, P. and Thomas, P. 2001. Irradiation for food safety and quality. Proc. FAO/IAEA/WHO, Turkey. Technomic Publishing Co. Inc.

Mahindru, S. N. 2005. Food preservation and irradiation. Aph Publishing Corporation. Chapter-8, p. 13.

Nagar, V. and Bandekar, J. R. 2011. Effectiveness of radiation processing in elimination of Aeromonas from food. Radiation Physics and Chemistry. 80(8): 911-916.

Obi, O. F., Anyadike, C. C. and Onyeke, C. O. 2014. Moisturedependent mechanical properties of pigeon pea grown in Nigeria. International Journal of Science, Environment and Technology. 3(3): 966975.

Ozden, O. and Erkan, N. 2010. Impacts of gamma radiation on nutritional 
components of minimal processed cultured sea bass (Dicentrarchuslabrax). Iranian Journal of Fisheries Sciences. 9(2): 265-278.

Panse, V. G. and Sukhatme, P. V. 1985. Statistical methods for agricultural workers. ICAR, New Delhi, p. 361.

Prado, G., Oliveira, M. S., Gazzinelli-Madeira, J. E. C., Godoy, I. J., Correa, B., Junqueira, R. G. and Ferreira, S. O. 1999. Resistance of aflatoxin $\mathrm{B} 1$ production by Aspergillusflavus Link its inoculation onto four peanuts genotypes. Food Science and Technology, 19(1): 84-87.

Ramamurthy, M. S., Kamat, A., Kakatkar, A., Ghadge, N., Bhushan, B. and Alur, M. 2004. Improvement of shelf-life and microbiological quality of minimally processed refrigerated capsicum by gamma irradiation. International Journal of Food Sciences and Nutrition. 55(4): 291-299.

Sharma, A. K. and Sharma, K. D. 1984. Changes in free fatty acids during fungal deterioration of fennel (Foeniculumvulgare Mill.) fruits. Phytopathologia Mediterranea. 23(1): 8182.

Sharma, A., Padwal- Desai, S. R. and Nair, P. M. 1989. Assessment of microbiological quality of some gamma irradiated Indian spices. Journal of Food Science. 54(2): 489-490.

Shea, K. M. and Committee on Environmental Health. 2000. Technical report: irradiation of food. Pediatrics. 106(6): 1505-1510.

Sheppard, A. J., and Rudolf, T. S. 1991. Analysis of peanuts and peanut products for total lipids, fatty acids and proximates. Peanut science. 18(1): 51-54.

Silberstein, O., Galetto, W. and Henzi, W. 1979. Irradiation of onion powder: effect on microbiology. Journal of Food Science. 44(1): 975-981.

Singh, L., Mohan, M. S. and Padwal-Desai, S. R. 1988. The use of gamma irradiation for improving microbiological qualities of spices. Journal of Food Science and Technology India. 25(1): 357-60.

Swailam, H. M. and Abdullah, M. I. 2002. Radiation sterilization of some spices and medicinal plant. Egyptian Journal of Microbiology. 2: 70-87.

Temur, C. and Osman, T. 2013. Irradiation alone or combined with other alternative treatments to control postharvest diseases. African Journal of Agricultural Research. 8(5): 421-434.

Thayer, D.W. and Boyd, G. L. E. N. N. 1993. Elimination of Escherichia coli O157: H7 in meats by gamma irradiation. Appl. Environ. Microbiol. 59(4): 1030-1034.

Youssef, B. M., Mahrous, S. R. and Aziz, N. H. 1999. Effect of gamma irradiation on aflatoxin B1 production by Aspergillus flavus in ground beef stored at 5C. Journal of food safety. 19(4): 231-239.

Yun, J., Li, X., Fan, X., Tang, Y., Xiao, Y. and Wan, S. 2012. Effect of gamma irradiation on microbial load, physicochemical and sensory characteristics of soybeans (Glycine max L. Merrill). Radiation Physics and Chemistry. 81(8): 1198-1202.

\section{How to cite this article:}

Gojiya, D. K., S. P. Cholera and Joshi, A. M. 2020. Influence of Gamma Irradiation on Microbial Load of Peanut (Arachis hypogaea L) Kernels. Int.J.Curr.Microbiol.App.Sci. 9(08): 589-602. doi: https://doi.org/10.20546/ijcmas.2020.908.066 